\title{
Macroeconomic Information and the Implied Volatility: Evidence from India VIX
}

\author{
Palamalai Srinivasan \\ Xavier Institute of Management \& Entrepreneurship, Bangalore, India \\ Email: srinivasaneco@gmail.com
}

How to cite this paper: Srinivasan, P. (2017) Macroeconomic Information and the Implied Volatility: Evidence from India VIX. Theoretical Economics Letters, 7, 490-501. https://doi.org/10.4236/tel.2017.73037

Received: March 13, 2017

Accepted: April 14, 2017

Published: April 17, 2017

Copyright $\odot 2017$ by author and Scientific Research Publishing Inc. This work is licensed under the Creative Commons Attribution International License (CC BY 4.0).

http://creativecommons.org/licenses/by/4.0/

\begin{abstract}
The present study attempts to examine the scheduled macroeconomic announcement effects on the India VIX using OLS regression model and the EGARCH model. The empirical results show that the information content of macroeconomic news on report day and day after does not have significant influences on India VIX, except MCIR. Besides, the findings reveal no significant response of India VIX during one day before the scheduled news announcements. This is due to the fact that India VIX market is more uncertain before the declaration of the results of MCIR convention of RBI, Export, Import, Fiscal Deficit, GDP, IIP and Inflation (CPI/WPI). The study shows that investors do not need to consider the scheduled macroeconomic announcement except MCIR meeting day and one day after in the valuation of options pricing or financial planning.
\end{abstract}

\section{Keywords}

Macroeconomic Announcements, Implied Volatility Index, India VIX, Leverage Effect

\section{Introduction}

The impact of information releases on stock prices has been well documented in the financial economic literature rather than the impact on option prices. One of the main challenges in options pricing is to understand the information contents that determine the volatility of asset prices. The renowned Black-Scholes-Merton option pricing model stated that call and put options pricing was reliant on the price of the underlying, strike price, risk free rate of interest, time to expiry and volatility. The market traders are conscious about these factors, except future volatility, at the time of shorting an option. The future volatility is unknown and subject to personal anxiety or fear of the option seller. This volatility is known as 
implied volatility and it replicates the sentiment of the option seller. If the option seller believes that the future volatility is high, higher premium is demanded for shorting an option, which makes option prices higher, and vice versa. Low value of Volatility Index (VIX) indicates stability in the market while high value indicated strain, fear and concern. The VIX measures the implied volatility in the market using the price levels of the index options. It is necessary in successful options trading to appraise the fair level of implied volatilities i.e. evaluate whether options are traded at too low or too high costs.

As the option prices replicate investors' sentiments and future cash flows, option implied volatility can include wider information set which incorporates scheduled macroeconomic news announcements, scheduled earnings announcements, etc. However, the market participants are conscious that some information will be provided to the market on a precise date but the content of the release is anonymous. Due to the ambiguity linked to the informational content of the announcement, investors anticipate a higher volatility on the releasing or reporting day. Accordingly, it should be observed that the implied volatility gradually rise during the announcement period, reach high on before the day news disseminates, and comeback to its normal level afterwards [1]. Academics, market participants and market analysts are of great interest in the behaviour of implied volatility as it provides a superior forecast of future volatility. This is due to the fact that when the new information disseminates in the market, under the market efficiency hypothesis, it will reflect in the underlying stock prices and thus VIX is the expectation of market participants for the future volatility. Besides, the information content of macroeconomic indicators holds great deal of interest since investors are aware of the important scheduled news and consider this news in their potential investment and portfolio risk management. A clearer conception about the announcements on the macroeconomic indicators that influence the slope is important for budding new option pricing models and devising appropriate hedging and investment strategies. Option traders and financial analysts closely monitor the behaviour of implied volatility index as they believe that it carries important information regarding the economic structure and the risk aversion of the participants in the market. In this study, the attempt has been made to investigate the behavior of India VIX during, before and after the scheduled macroeconomic news release.

\section{Literature Review}

The earlier studies such as Ederington and Lee [2] [3], Thorbecke [4], Bomfim [5] and Kearney and Lombra [6] had shown that asset prices volatility and implied volatility increases significantly prior to the macroeconomic announcement and goes normal on the day of news release. Graham et al. [7], Nikkinen and Sahlstrom [1], Nikkinen et al. [8] and Chen and Clements [9] studied the impact of macroeconomic announcements on stock return and implied volatility index and found that these markets respond significantly to the scheduled news and also revealed that VIX increases prior to the scheduled announcement and 
remain more stable on the day of announcement. Gospodinov and Jamali [10] analysed the impact of Federal Open Market Committee (FOMC) statement releases on US VIX index and found that volatility index responds positively and significantly on federal fund rate surprises. Also, the study results showed that macroeconomic variables viz. industrial produce, employment rate, GDP growth rate and Inflation significantly affects implied volatility index. Marshall et al. [11] concluded that implied volatility is significantly affected by macroeconomic news release and also showed that scheduled announcements make the implied volatility falls on the announcement day but no considerable change observed on pre and post announcements. On the other hand, Aijo [12] explained that good (bad) news caused implied volatility to fall (rise).

It is clearly seen that the empirical evidences on the subject is found to be contradictory. To the best of knowledge, the Shaikh and Padhi [13] is the only study attempted to investigate the response of Implied Volatility Index towards the scheduled macroeconomic announcements in the Indian context. Using the Ordinary Least Squares (OLS) and Generalised Autoregressive Conditional Heteroscedasticity (GARCH) models, they found that IVIX rises significantly prior to the scheduled announcement and remains more stable on the new releases. However, the GARCH models used in their study assumes the symmetric behaviour of market reactions towards positive and negative news and therefore, cannot capture the leverage effect. Meanwhile, in another study, Shaikh and Padhi [14] investigated the asymmetric contemporaneous relationship between India VIX and NIFTY Index and they proved that the changes in India VIX occur bigger for the negative return shocks than the positive returns shocks. In this situation, the application of GARCH-type models by Shaikh and Padhi [13] are mis-specified and lead to biased estimates of volatilities, as well as to inaccurate forecast intervals. To model the asymmetry in implied volatility index and allow the possibility to measure the different impact on the conditional variance of bad and good news, the Exponential Generalised Autoregressive Conditional Heteroscedasticity (EGARCH) model offered by Nelson [15] and Engle et al. [16] was used in the present study to investigate the behavior of India VIX during, before and after the scheduled macroeconomic news release. Besides, the EGARCH model, unlike the linear GARCH models, uses the natural logarithm of the conditional variance to relax the non-negativity constraint of the model's coefficients and to allow for the persistence of shocks to the conditional variance.

\section{Methodology}

In order to investigate the behaviour of India VIX on scheduled macroeconomic announcements, the present study employed OLS (Ordinary Least Squares) and Exponential Generalized Autoregressive Conditional Heteroscedasticity (EGARCH) models based on following specifications. The analysis was done with the help of EVIEWS 9 econometric software package.

\section{OLS Model 1:}




$$
\begin{aligned}
\Delta \text { IVIX }_{t}= & \alpha_{0}+\beta_{1} \text { EXPORT }_{t}+\beta_{2} \text { FISCALDEFICIT }_{t} \\
& +\beta_{3} \text { GDP }_{t}+\beta_{4} \mathrm{IIP}_{t}+\beta_{5} \mathrm{IMPORT}_{t} \\
& +\beta_{6} \text { INFLATION }_{t}+\beta_{7} \text { MCIR }_{t}+\omega_{t}
\end{aligned}
$$

EGARCH Model 2:

Mean Equation:

$$
\begin{aligned}
\Delta \text { IVIX }_{t}= & \alpha_{0}+\beta_{8} \text { EXPORT }_{t}+\beta_{9} \text { FISCALDEFICIT }_{t} \\
& +\beta_{10} \mathrm{GDP}_{t}+\beta_{11} \mathrm{IIP}_{t}+\beta_{12} \mathrm{IMPORT}_{t} \\
& +\beta_{13} \mathrm{INFLATION}_{t}+\beta_{14} \mathrm{MCIR}_{t}+\omega_{t}
\end{aligned}
$$

Variance Equation:

$$
\log \left(h_{t}\right)=\alpha+\sum_{j=1}^{q} \beta_{j}\left|\frac{u_{t-j}}{\sqrt{h_{t-j}}}\right|+\sum_{j=1}^{q} \lambda_{j} \frac{u_{t-j}}{\sqrt{h_{t-j}}}+\sum_{i=1}^{p} \delta_{i} h_{t-1}
$$

OLS Model 3:

$$
\begin{aligned}
\Delta \text { IVIX }_{t}= & \alpha_{0}+\beta_{15} \text { EXPORT }_{t-1}+\beta_{16} \text { FISCALDEFICIT }_{t-1} \\
& +\beta_{17} \mathrm{GDP}_{t-1}+\beta_{18} \mathrm{IIP}_{t-1}+\beta_{19} \mathrm{IMPORT}_{t-1} \\
& +\beta_{20} \mathrm{INFLATION}_{t-1}+\beta_{21} \mathrm{MCIR}_{t-1}+\omega_{t}
\end{aligned}
$$

EGARCH Model 4:

Mean Equation:

$$
\begin{aligned}
\Delta \text { IVIX }_{t}= & \alpha_{0}+\beta_{22} \text { EXPORT }_{t-1}+\beta_{23} \text { FISCALDEFICIT }_{t-1} \\
& +\beta_{24} \text { GDP }_{t-1}+\beta_{25} \mathrm{IIP}_{t-1}+\beta_{26} \text { IMPORT }_{t-1} \\
& +\beta_{27} \text { INFLATION }_{t-1}+\beta_{28} \text { MCIR }_{t-1}+\omega_{t}
\end{aligned}
$$

Variance Equation:

$$
\log \left(h_{t}\right)=\alpha_{1}+\sum_{j=1}^{q} \beta_{j}\left|\frac{u_{t-j}}{\sqrt{h_{t-j}}}\right|+\sum_{j=1}^{q} \lambda_{j} \frac{u_{t-j}}{\sqrt{h_{t-j}}}+\sum_{i=1}^{p} \delta_{i} h_{t-1}
$$

OLS Model 5:

$$
\begin{aligned}
\operatorname{SIVIX}_{t}= & \alpha_{0}+\beta_{29} \text { EXPORT }_{t+1}+\beta_{30} \text { FISCALDEFICIT }_{t+1} \\
& +\beta_{31} \mathrm{GDP}_{t+1}+\beta_{32} \mathrm{IIP}_{t+1}+\beta_{33} \mathrm{IMPORT}_{t+1} \\
& +\beta_{34} \mathrm{INFLATION}_{t+1}+\beta_{35} \text { MCIR }_{t+1}+\omega_{t}
\end{aligned}
$$

EGARCH Model 6:

Mean Equation:

$$
\begin{aligned}
\operatorname{SIVIX}_{t}= & \alpha_{0}+\beta_{29} \text { EXPORT }_{t+1}+\beta_{30} \text { FISCALDEFICIT }_{t+1} \\
& +\beta_{31} \mathrm{GDP}_{t+1}+\beta_{32} \mathrm{IIP}_{t+1}+\beta_{33} \mathrm{IMPORT}_{t+1} \\
& +\beta_{34} \text { INFLATION }_{t+1}+\beta_{35} \text { MCIR }_{t+1}+\omega_{t}
\end{aligned}
$$

Variance Equation:

$$
\log \left(h_{t}\right)=\alpha+\sum_{j=1}^{q} \beta_{j}\left|\frac{u_{t-j}}{\sqrt{h_{t-j}}}\right|+\sum_{j=1}^{q} \lambda_{j} \frac{u_{t-j}}{\sqrt{h_{t-j}}}+\sum_{i=1}^{p} \delta_{i} h_{t-1}
$$

OLS Model 7: 


$$
\begin{aligned}
\text { IVIX }_{t}= & \alpha_{0}+\beta_{43} \text { EXPORT }_{t}+\beta_{44} \text { FISCALDEFICIT }_{t} \\
& +\beta_{45} \mathrm{GDP}_{t}+\beta_{46} \mathrm{IIP}_{t}+\beta_{47} \mathrm{IMPORT}_{t}+\beta_{48} \mathrm{INFLATION}_{t} \\
& +\beta_{49} \mathrm{MCIR}_{t}+\beta_{50} \mathrm{EXPORT}_{t-1}+\beta_{51} \mathrm{FISCALDEFICIT}_{t-1} \\
& +\beta_{52} \mathrm{GDP}_{t-1}+\beta_{53} \mathrm{IIP}_{t-1}+\beta_{54} \mathrm{IMPORT}_{t-1}+\beta_{55} \text { INFLATION }_{t-1} \\
& +\beta_{56} \mathrm{MCIR}_{t-1}+\beta_{57} \mathrm{EXPORT}_{t+1}+\beta_{58} \text { FISCALDEFICIT }_{t+1} \\
& +\beta_{59} \mathrm{GDP}_{t+1}+\beta_{60} \mathrm{IIP}_{t+1}+\beta_{61} \mathrm{IMPORT}_{t+1} \\
& +\beta_{62} \mathrm{INFLATION}_{t+1}+\beta_{63} \mathrm{MCIR}_{t+1}+\omega_{t}
\end{aligned}
$$

\section{EGARCH Model 8:}

\section{Mean Equation:}

$$
\begin{aligned}
\Delta \text { IVIX }_{t}= & \alpha_{0}+\beta_{64} \text { EXPORT }_{t}+\beta_{65} \text { FISCALDEFICIT }_{t} \\
& +\beta_{66} \mathrm{GDP}_{t}+\beta_{67} \mathrm{IIP}_{t}+\beta_{68} \mathrm{IMPORT}_{t}+\beta_{69} \mathrm{INFLATION}_{t} \\
& +\beta_{70} \mathrm{MCIR}_{t}+\beta_{71} \mathrm{EXPORT}_{t-1}+\beta_{72} \mathrm{FISCALDEFICIT}_{t-1} \\
& +\beta_{73} \mathrm{GDP}_{t-1}+\beta_{74} \mathrm{IIP}_{t-1}+\beta_{75} \mathrm{IMPORT}_{t-1}+\beta_{76} \mathrm{INFLATION}_{t-1} \\
& +\beta_{77} \mathrm{MCIR}_{t-1}+\beta_{78} \mathrm{EXPORT}_{t+1}+\beta_{79} \mathrm{FISCALDEFICIT}_{t+1} \\
& +\beta_{80} \mathrm{GDP}_{t+1}+\beta_{81} \mathrm{IIP}_{t+1}+\beta_{82} \mathrm{IMPORT}_{t+1} \\
& +\beta_{83} \mathrm{INLATION}_{t+1}+\beta_{84} \mathrm{MCIR}_{t+1}+\omega_{t}
\end{aligned}
$$

Variance Equation:

$$
\log \left(h_{t}\right)=\alpha+\sum_{j=1}^{q} \beta_{j}\left|\frac{u_{t-j}}{\sqrt{h_{t-j}}}\right|+\sum_{j=1}^{q} \lambda_{j} \frac{u_{t-j}}{\sqrt{h_{t-j}}}+\sum_{i=1}^{p} \delta_{i} h_{t-1}
$$

where $\omega_{t}$ is the error term, and $\Delta I V I X_{t}$ represent changes in the India's VIX. $\beta s$ explains the impact of scheduled macroeconomic announcements on VIX and the macroeconomic variables associated with $\beta s$ are the dummy variables, assumes one on the important announcements days otherwise it is zero. $\alpha_{0}$ captures the behaviour of India VIX during the non-announcement periods. $t, t$ -1 and $t+1$ represents time period, viz. reporting day, one day before and one day after the announcement of macroeconomic news, respectively. Based on the study of Ederington and Lee [5], Nikkinen and Sahlstrom [13] and Chen and Clements [3], we expect that during the non-announcements days, the VIX rises hence intercept $\left(\alpha_{0}\right)$ should be non-zero and positive, and also should be statistically significant. On the scheduled macroeconomic news release day, the VIX should go down, and goes its normal level, as it impounds the information disclosure. Hence, all the slope coefficients $(\beta s)$ scheduled news of macroeconomic indicators should be negative, and should be statistically significant. Before the scheduled news announcements VIX rises significantly. Hence, all the slope coefficients $(\beta s)$ scheduled news of macroeconomic indicators should be positive and statically significant. After the announcements of scheduled news, VIX goes its normal level, i.e. it declines up to certain days. Hence, all the slope coefficients ( $\beta s$ ) scheduled news of macroeconomic indicators should be negative, and should be statistically significant. Under the EGARCH Models, $h_{t}$ represents the conditional variance; $\delta_{i}$ shows the GARCH effect i.e. persistent Large GARCH coefficient implies that higher persistence of volatility shocks. $\lambda$ captures the asymmetric effect which means that the higher volatility response to a 
large negative return caused by bad news than it is to a large positive return of the same magnitude due to good news. The exponential nature of EGARCH guarantees that the conditional variation is always positive even if the parameter values are negative; thus there is no requisite for parameter restrictions to inflict non-negativity.

The macroeconomic schedule announcements on Gross Domestic Product (GDP), Index of Industrial Production (IIP), Fiscal Deficit, Export, Import, Inflation (represented by CPI/WPI) and MCIR are considered for the study. As per the IMF (International Monetary Fund) guidelines, every country has to maintain special data dissemination standard (SDDS), under this provision RBI disseminates the data on Monetary and Credit Information Review (MCIR) which mainly consists of information announcements on Reverse Repo Rate, Repurchase Rate and Cash Reserve Ratio. The sample period for the study is considered from $2^{\text {nd }}$ March 2009 to $31^{\text {st }}$ August 2016. The macroeconomic indicators considered in the study are available based on their schedule, after the normal market is open around $11.00 \mathrm{am}$ (ISD). Accordingly, the content of the news enter in the market on the day of actual announcement. The necessary information on daily closing prices of the India VIX is taken from the web site of National Stock Exchange of India (NSE) and the macroeconomic schedule announcements on each indicator viz. Gross Domestic Product (GDP), Index of Industrial Production (IIP), Fiscal Deficit, Export, Import, Inflation (represented by $\mathrm{CPI} / \mathrm{WPI}$ ) and MCIR are collected from the Bloomberg database.

\section{Empirical Results}

Table 1 shows the descriptive statistics of IVIX for the sample period of $2^{\text {nd }}$ March 2009 to $31^{\text {st }}$ August 2016. The average IVIX for the sample period average IVIX is found to be 21.36 points with an average negative return of 0.06 percent. The highest VIX points observed for the period is 56.07 and lowest is 11.56. The table results show that log-returns series of IVIX is positively skewed and leptokurtic. The Jarque-Bera statistic rejects the null hypothesis, at one percent significant level, that the return series is normal against the alternative hypothesis that the return series is non-normal. The modified Dickey-Fuller test statistic (known as the DF-GLS test) is statistically significant at one percent level, signifies that the log-returns series is stationary. Moreover, the Kwiatkowski-PhillipsSchmidt-Shin (KPSS) test statistic accepts the null hypothesis that the log-return series is stationary. Besides, the Figure 1 shows the time-series plot of IVIX index, implying that there is no problem of trend in the time series of IVIX. To test whether there is ARCH effect in the log-return series of IVIX during the study period, the Engle [17] ARCH-LM test statistics was employed and it reveals significant ARCH effect at one per cent level, hence the results warrant for the estimation of GARCH family models.

In order to examine the scheduled monetary and macroeconomic announcement effects on the India VIX, the OLS model and EGARCH model were employed and the results are depicted in Table 2. Based on the proposition, devel- 
oped by the previous studies such as Ederington and Lee [3], Nikkinen and Sahlstrom [1] and Chen and Clements [9], it is expected that during the non-announcements days, the IVIX rises hence the intercept is expected to be non-zero (positive) and should be statistically significant. On the scheduled macroeconomic news release day, the IVIX should falls and reaches its normal level, as it impounds the information disclosure. Hence, the slope coefficients of EXPORT, FISCAL DEFICIT, GDP, IIP, IMPORT, INFLATION and MCIR expected to be negative and statistically significant. Before the scheduled news announcements, the IVIX rises significantly and thus, the slope coefficients of EXPORT, FISCAL DEFICIT, GDP, IIP, IMPORT, INFLATION and MCIR expected to be positive and statically significant. After the announcements of

Table 1. Descriptive statistics of India's VIX.

\begin{tabular}{ccc}
\hline Statistics & IVIX (level) & Log-Returns of IVIX \\
\hline Mean & 21.36 & -0.0006 \\
Median & 19.25 & -0.002 \\
Maximum & 56.07 & 0.496 \\
Minimum & 11.56 & -0.414 \\
Std. Dev. & 7.315 & 0.051 \\
Skewness & 1.690 & 0.428 \\
Kurtosis & 6.357 & 10.84 \\
Jarque-Bera statistics & $1759.5^{*}(0.000)$ & $4824.2^{*}(0.000)$ \\
KPSS test statistics & $2.469^{*}$ & 0.047 \\
DF-GLS test statistics & -0.869 & $-4.890^{*}$ \\
ARCH-LM statistics & 1860 & $12.27^{*}(0.000)$ \\
Observations & $*$ & 1860 \\
\hline
\end{tabular}

Figures in the parenthesis ( ) indicates p-value. ${ }^{*}$ denote the significance at one percent level.

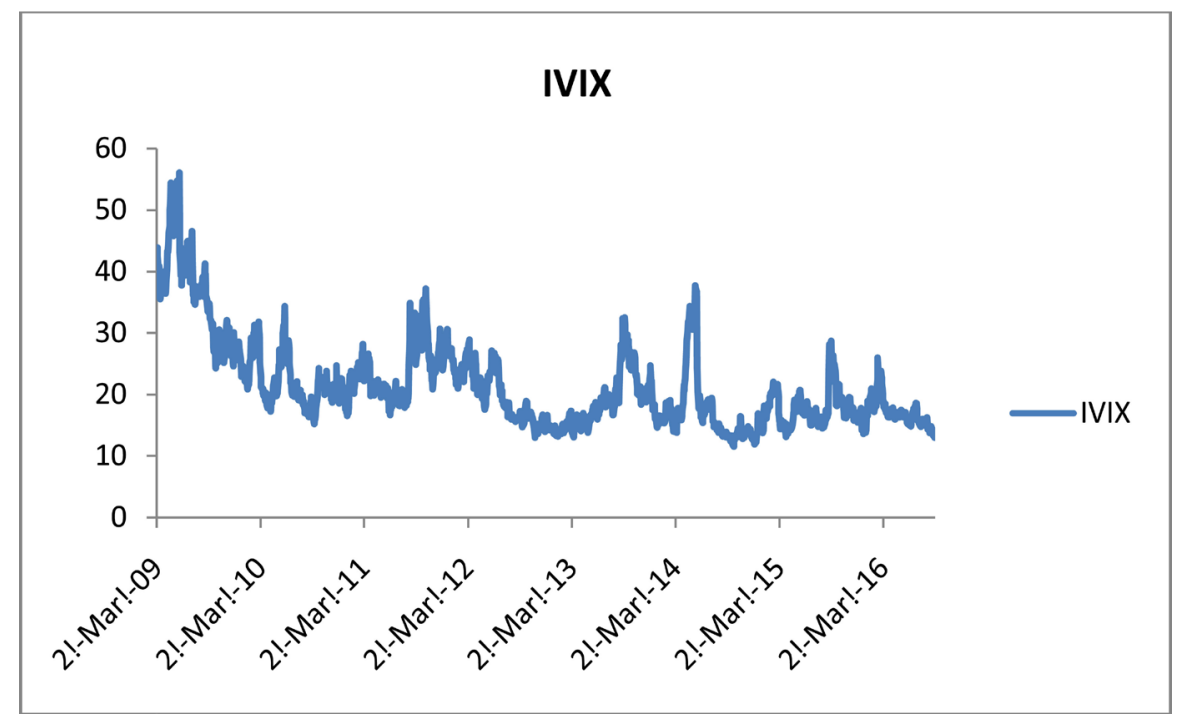

Figure 1. Time Series Plot of IVIX index. 
Table 2. Impact of Macroeconomic announcements on the implied volatility index (Dependent Variable: Log-Returns of IVIX).

\begin{tabular}{|c|c|c|c|c|c|c|c|c|}
\hline \multirow{2}{*}{$\begin{array}{c}\text { Independent } \\
\text { Variables }\end{array}$} & $\begin{array}{l}\text { Model } \\
\text { 1: OLS }\end{array}$ & $\begin{array}{l}\text { Model 2: } \\
\text { EGARCH }\end{array}$ & Independent & $\begin{array}{l}\text { Model 3: } \\
\text { OLS }\end{array}$ & $\begin{array}{l}\text { Model 4: } \\
\text { EGARCH }\end{array}$ & Independent & $\begin{array}{l}\text { Model 5: } \\
\text { OLS }\end{array}$ & $\begin{array}{l}\text { Model 6: } \\
\text { EGARCH }\end{array}$ \\
\hline & Estimate & Estimate & & Estimate & Estimate & & Estimate & Estimate \\
\hline Constant & $\begin{array}{l}0.0002 \\
(0.221)\end{array}$ & $\begin{array}{c}0.001 \\
{[1.110]}\end{array}$ & Constant & $\begin{array}{l}0.0009 \\
(0.720)\end{array}$ & $\begin{array}{l}0.0003 \\
{[0.252]}\end{array}$ & Constant & $\begin{array}{l}0.0007 \\
(0.555)\end{array}$ & $\begin{array}{l}0.0003 \\
{[0.263]}\end{array}$ \\
\hline $\begin{array}{c}\text { EXPORT report } \\
\text { day }\end{array}$ & $\begin{array}{c}0.018 \\
(0.500)\end{array}$ & $\begin{array}{c}0.011 \\
{[0.173]}\end{array}$ & $\begin{array}{l}\text { EXPORT report } \\
\text { one day before }\end{array}$ & $\begin{array}{c}0.063 \\
(1.714)\end{array}$ & $\begin{array}{c}0.062 \\
{[1.278]}\end{array}$ & $\begin{array}{l}\text { EXPORT report } \\
\text { one day after }\end{array}$ & $\begin{array}{l}-0.038 \\
(-1.062)\end{array}$ & $\begin{array}{c}-0.035 \\
{[-1.043]}\end{array}$ \\
\hline $\begin{array}{l}\text { FISCAL DEFICIT } \\
\text { report day }\end{array}$ & $\begin{array}{l}-0.003 \\
(-0.417)\end{array}$ & $\begin{array}{c}0.0002 \\
{[0.033]}\end{array}$ & $\begin{array}{c}\text { FISCAL } \\
\text { DEFICIT report } \\
\text { one day before }\end{array}$ & $\begin{array}{c}0.008 \\
(1.068)\end{array}$ & $\begin{array}{c}0.012 \\
{[1.912]}\end{array}$ & $\begin{array}{l}\text { FISCAL DEFICIT } \\
\text { report one day } \\
\text { after }\end{array}$ & $\begin{array}{l}-0.009 \\
(-1.133)\end{array}$ & $\begin{array}{c}-0.008 \\
{[-1.114]}\end{array}$ \\
\hline GDP report day & $\begin{array}{l}-0.011 \\
(-1.095)\end{array}$ & $\begin{array}{c}-0.009 \\
{[-1.023]}\end{array}$ & $\begin{array}{l}\text { GDP report one } \\
\text { day before }\end{array}$ & $\begin{array}{l}-0.002 \\
(-0.212)\end{array}$ & $\begin{array}{c}-0.005 \\
{[-0.591]}\end{array}$ & $\begin{array}{l}\text { GDP report one } \\
\text { day after }\end{array}$ & $\begin{array}{l}-0.013 \\
(-1.271)\end{array}$ & $\begin{array}{c}0.004 \\
{[0.516]}\end{array}$ \\
\hline IIP report day & $\begin{array}{l}-0.004 \\
(-0.773)\end{array}$ & $\begin{array}{l}-0.005 \\
{[-0.951]}\end{array}$ & $\begin{array}{l}\text { IIP report one } \\
\text { day before }\end{array}$ & $\begin{array}{l}-0.004 \\
(-0.680)\end{array}$ & $\begin{array}{c}-0.002 \\
{[-0.432]}\end{array}$ & $\begin{array}{l}\text { IIP report one day } \\
\text { after }\end{array}$ & $\begin{array}{c}0.009 \\
(1.532)\end{array}$ & $\begin{array}{c}0.005 \\
{[0.893]}\end{array}$ \\
\hline $\begin{array}{l}\text { IMPORT report } \\
\text { day }\end{array}$ & $\begin{array}{l}-0.020 \\
(-0.550)\end{array}$ & $\begin{array}{l}-0.011 \\
{[-0.176]}\end{array}$ & $\begin{array}{l}\text { IMPORT report } \\
\text { one day before }\end{array}$ & $\begin{array}{l}-0.057 \\
(-1.570)\end{array}$ & $\begin{array}{l}-0.057 \\
{[-1.165]}\end{array}$ & $\begin{array}{l}\text { IMPORT report } \\
\text { one day after }\end{array}$ & $\begin{array}{c}0.033 \\
(0.907)\end{array}$ & $\begin{array}{c}0.031 \\
{[0.905]}\end{array}$ \\
\hline $\begin{array}{l}\text { INFLATION } \\
\text { report day }\end{array}$ & $\begin{array}{l}0.005 \\
(0.857)\end{array}$ & $\begin{array}{c}0.005 \\
{[0.755]}\end{array}$ & $\begin{array}{l}\text { INFLATION } \\
\text { report one day } \\
\text { before }\end{array}$ & $\begin{array}{l}-0.0006 \\
(-0.109)\end{array}$ & $\begin{array}{c}0.002 \\
{[0.367]}\end{array}$ & $\begin{array}{l}\text { INFLATION } \\
\text { report one day } \\
\text { after }\end{array}$ & $\begin{array}{l}-0.005 \\
(-0.801)\end{array}$ & $\begin{array}{c}-0.004 \\
{[-0.839]}\end{array}$ \\
\hline MCIR report day & $\begin{array}{l}-0.020^{*} \\
(-2.812)\end{array}$ & $\begin{array}{l}-0.017^{\star} \\
{[-2.783]}\end{array}$ & $\begin{array}{l}\text { MCIR report one } \\
\text { day before }\end{array}$ & $\begin{array}{c}0.003 \\
(0.508)\end{array}$ & $\begin{array}{c}0.003 \\
{[0.386]}\end{array}$ & $\begin{array}{l}\text { MCIR report one } \\
\text { day after }\end{array}$ & $\begin{array}{l}0.019^{\star} \\
(2.739)\end{array}$ & $\begin{array}{c}0.023^{*} \\
{[3.489]}\end{array}$ \\
\hline GARCH effect & & $\begin{array}{l}0.967^{*} \\
{[199.2]}\end{array}$ & & & $\begin{array}{c}0.969^{\star} \\
{[214.08]}\end{array}$ & & & $\begin{array}{l}0.964^{*} \\
{[166.7]}\end{array}$ \\
\hline Leverage effect & & $\begin{array}{l}0.115^{*} \\
{[13.31]}\end{array}$ & & & $\begin{array}{l}0.117^{\star} \\
{[13.76]}\end{array}$ & & & $\begin{array}{l}0.115^{\star} \\
{[12.44]}\end{array}$ \\
\hline $\begin{array}{l}\text { ARCH-LM } \\
\text { Statistics }\end{array}$ & & $\begin{array}{c}0.876 \\
\{0.349\}\end{array}$ & & & $\begin{array}{c}0.737 \\
\{0.390\}\end{array}$ & & & $\begin{array}{c}0.716 \\
\{0.397\}\end{array}$ \\
\hline
\end{tabular}

*denote the significance at one percent level. Parentheses ( ), [ ] and \{\} indicates t-values, z-values and probability values, respectively.

scheduled news, VIX reaches its normal level, i.e. it diminishes up to certain days. Hence, the slope coefficients of EXPORT, FISCAL DEFICIT, GDP, IIP, IMPORT, INFLATION and MCIR expected to be negative and statistically significant.

Model 1 and 2 studies the behavior of IVIX during the report day of the announcements using OLS and EGARCH model, respectively. It is under the assumptions that investors consider the scheduled macroeconomic announcements in their financial planning. It is observed that the intercept appears non-zero but positive in the case of report day and statistically insignificant. This shows that on the non-announcement day there is an uncertainty in the market and the investor overreacts but it is does not impacted the IVIX. Besides, the slope coefficients of EXPORT, FISCAL DEFICIT, GDP, IIP, IMPORT and INFLATION on the report day are found to be insignificant. Only the slope of the MCIR is found to be negative and statistically significant on the macroeconomic announcements day in the case of Model 1 and 2. This implies that the 
IVIX falls on the report day with regards to the announcements on MCIR news, suggesting the information content of MCIR have the greatest impact on the valuation of financial assets.

Model 3 and 4 studies the behavior of IVIX during a day before the macroeconomic announcements. The intercepts in both the models are found to be positive, but statistically insignificant during one day before the scheduled announcements. In addition, it is seen that there are no slope coefficients are found to be statistically significant in the case of both models except MCIR information contents. Model 5 and 6 shows the behavior of IVIX during a day after the macroeconomic announcements. The intercept coefficients in both the model are found to be positive and statistically insignificant during a day after the scheduled announcements. The slope of the MCIR announcements is found to be positive and statistically significant in the case of both models, implying that the IVIX rises after the scheduled announcements of MICR content. It is expected that the IVIX should decrease after the scheduled announcements of macroeconomic information. However, the scheduled macroeconomic news releases are not found to be important in influencing the behavior of India VIX except MCIR. Under the EGARCH estimations, the GARCH coefficients are found to be statistically significant, suggesting that once a shock has occurred, volatility tends to persist for long periods. Besides, the leverage coefficients in all the models are found to be positive and statistically significant signifying the leverage effect i.e. positive shocks (good news) have a greater impact on conditional volatility of the India VIX than negative shocks (bad news) of equal magnitude. Moreover, the ARCH-LM tests statistics are found to be insignificant in all the estimated EGARCH models and confirms the absence of any further ARCH effects.

Table 3 provides the empirical results of scheduled monetary and macroeconomic announcement effects on the India VIX which are estimated with the inclusion all the variables during the report day, one day before and after scheduled announcements. From the Model 7 and 8, it is clearly seen that the, except MCIR, the slope coefficients of EXPORT, FISCAL DEFICIT, GDP, IIP, IMPORT and INFLATION on the report day are found to be insignificant. The MCIR report day is found to be negative and statistically significant in the case of Model 7 and 8 and this confirms that the IVIX falls on the report day with regards to the announcements on MCIR news. It is also seen that there are no slope coefficients of scheduled announcements one day before are found to be statistically significant in the case of both OLS and EGARCH models. Moreover, the findings reveal that the slope of the MCIR announcements is found to be positive and statistically significant in the case of both models, implying that the IVIX rises after the scheduled announcements of MICR content. Under the EGARCH estimate, the GARCH effect is found to be statistically significant, suggesting that once a shock has occurred, volatility tends to persist for long periods. Besides, the leverage coefficient is positive and statistically significant indicating that positive shocks (good news) have a greater impact on conditional volatility of the India VIX than negative shocks (bad news) of equal magnitude. Moreover, 
Table 3. Results based on the report day, one day before and after scheduled announcements (Dependent Variable: Log-Returns of IVIX).

\begin{tabular}{|c|c|c|}
\hline \multirow{2}{*}{ Independent Variables } & Model 7 & Model 8 \\
\hline & Estimate & Estimate \\
\hline Constant & $\begin{array}{l}-0.0001 \\
(-0.104)\end{array}$ & $\begin{array}{l}0.0004 \\
{[0.273]}\end{array}$ \\
\hline EXPORT report day & $\begin{array}{c}0.018 \\
(0.504)\end{array}$ & $\begin{array}{c}0.020 \\
{[0.321]}\end{array}$ \\
\hline FISCAL DEFICIT report day & $\begin{array}{c}-0.004 \\
(-0.562)\end{array}$ & $\begin{array}{c}-0.001 \\
{[-0.183]}\end{array}$ \\
\hline GDP report day & $\begin{array}{c}-0.010 \\
(-0.945)\end{array}$ & $\begin{array}{c}-0.008 \\
{[-0.876]}\end{array}$ \\
\hline IIP report day & $\begin{array}{c}-0.004 \\
(-0.631)\end{array}$ & $\begin{array}{c}-0.005 \\
{[-0.869]}\end{array}$ \\
\hline IMPORT report day & $\begin{array}{c}-0.020 \\
(-0.547)\end{array}$ & $\begin{array}{c}-0.020 \\
{[-0.309]}\end{array}$ \\
\hline INFLATION report day & $\begin{array}{c}0.006 \\
(1.006)\end{array}$ & $\begin{array}{c}0.006 \\
{[0.930]}\end{array}$ \\
\hline MCIR report day & $\begin{array}{l}-0.019^{\star} \\
(-2.715)\end{array}$ & $\begin{array}{c}-0.017^{\star} \\
{[-2.676]}\end{array}$ \\
\hline EXPORT report one day before & $\begin{array}{c}0.066 \\
(1.566)\end{array}$ & $\begin{array}{c}0.067 \\
{[1.139]}\end{array}$ \\
\hline FISCAL DEFICIT report one day before & $\begin{array}{c}0.006 \\
(0.759)\end{array}$ & $\begin{array}{c}0.009 \\
{[1.463]}\end{array}$ \\
\hline GDP report one day before & $\begin{array}{l}-0.002 \\
(-0.232)\end{array}$ & $\begin{array}{c}-0.007 \\
{[-0.733]}\end{array}$ \\
\hline IIP report one day before & $\begin{array}{l}-0.005 \\
(-0.758)\end{array}$ & $\begin{array}{c}-0.003 \\
{[-0.574]}\end{array}$ \\
\hline IMPORT report one day before & $\begin{array}{l}-0.061 \\
(-1.453)\end{array}$ & $\begin{array}{c}-0.060 \\
{[-1.034]}\end{array}$ \\
\hline INFLATION report one day before & $\begin{array}{c}-0.001 \\
(-0.237)\end{array}$ & $\begin{array}{c}0.002 \\
{[0.382]}\end{array}$ \\
\hline MCIR report one day before & $\begin{array}{c}0.003 \\
(0.468)\end{array}$ & $\begin{array}{c}0.002 \\
{[0.343]}\end{array}$ \\
\hline EXPORT report one day after & $\begin{array}{c}-0.005 \\
(-0.118)\end{array}$ & $\begin{array}{c}-0.003 \\
{[-0.056]}\end{array}$ \\
\hline FISCAL DEFICIT report one day after & $\begin{array}{c}-0.008 \\
(-1.026)\end{array}$ & $\begin{array}{c}-0.007 \\
{[-0.932]}\end{array}$ \\
\hline GDP report one day after & $\begin{array}{c}-0.013 \\
(-1.345)\end{array}$ & $\begin{array}{c}0.003 \\
{[0.430]}\end{array}$ \\
\hline IIP report one day after & $\begin{array}{c}0.008 \\
(1.318)\end{array}$ & $\begin{array}{c}0.004 \\
{[0.687]}\end{array}$ \\
\hline IMPORT report one day after & $\begin{array}{l}0.0004 \\
(0.010)\end{array}$ & $\begin{array}{c}-0.0001 \\
{[-0.002]}\end{array}$ \\
\hline INFLATION report one day after & $\begin{array}{c}-0.002 \\
(-0.369)\end{array}$ & $\begin{array}{c}-0.001 \\
{[-0.195]}\end{array}$ \\
\hline MCIR report one day after & $\begin{array}{l}0.019^{*} \\
(2.599)\end{array}$ & $\begin{array}{l}0.022^{\star} \\
{[3.455]}\end{array}$ \\
\hline GARCH effect & & $\begin{array}{l}0.967^{*} \\
{[190.7]}\end{array}$ \\
\hline Leverage effect & & $\begin{array}{l}0.118^{*} \\
{[12.94]}\end{array}$ \\
\hline ARCH-LM Statistics & & $\begin{array}{c}0.826 \\
\{0.363\}\end{array}$ \\
\hline
\end{tabular}

*denote the significance at one percent level. Parentheses ( ), [ ] and \{\} indicates t-values, $\mathrm{z}$-values and probability values, respectively. 
the insignificant ARCH-LM test statistics confirms the absence of any further ARCH effects in the residuals of EGARCH model.

\section{Conclusions}

The present study attempts to examine the scheduled monetary and macroeconomic announcement effects on the India VIX using OLS regression model and the EGARCH model. This study is based on the behavior of India's VIX during the series of scheduled macroeconomic news releases such as EXPORT, FISCAL DEFICIT, GDP, IIP, IMPORT, INFLATION (CPI/WPI) and MCIR for the period $2^{\text {nd }}$ March 2009 to $31^{\text {st }}$ August 2016. It is anticipated that the IVIX should decrease on the day of scheduled announcements of macroeconomic information and the day after information release. However, the empirical results show that the information content of macroeconomic news on report day and day after does not have significant influences on India VIX, except MCIR. Besides, the findings reveal no significant response of India VIX during one day before the scheduled news announcements. This is due to the fact that India VIX market is more uncertain before the declaration of the results of MCIR convention of RBI, Export, Import, Fiscal Deficit, GDP, IIP and Inflation (CPI/WPI). Based on the previous studies, it is postulated that before the announcement of macroeconomic news, the implied volatility index increases significantly and on the day of macroeconomic announcements, uncertainty about the news gets resolved and VIX goes its customary level. Moreover, the efficient market hypothesis explained that if the market is efficient, it responds to the important macroeconomic information releases. Accordingly, the investors should take into account these news releases in their portfolio selection. However, the major findings of the study suggests that investors need not to consider the scheduled macroeconomic announcement except MCIR meeting day and one day after in the valuation of options pricing or financial planning due to the inefficiency of the Indian options market. These results are contradictory with the findings of Shaikh and Padhi [13] in the Indian context.

The study can be extended in terms of response of India VIX for the economic news of Europe, US and other emerging economies. The present study is based on index level investigation, thus there is scope for concerning the behaviour of India implied volatility to the firm-specific announcements. Further studies may examine the response of predictive power of volatility index and examine the co-movements of IVIX with other global volatility indices.

\section{References}

[1] Nikkinen, J. and Sahlstrom, P. (2004) Impact of Federal Open Market Committee's Meetings and Scheduled Macroeconomic News on Stock Market Uncertainty. International Review of Financial Analysis, 13, 1-12.

[2] Ederington, L.H. and Lee, J.H. (1993) How Markets Process Information: News Releases and Volatility. Journal of Finance, 48, 1161-1191. https://doi.org/10.1111/j.1540-6261.1993.tb04750.x

[3] Ederington, L.H. and Lee, J.H. (1996) The Creation and Resolution of Market Un- 
certainty: The Impact of Information Releases on Implied Volatility. Journal of Financial and Quantitative Analysis, 31, 513-539. https://doi.org/10.2307/2331358

[4] Thorbecke, W. (1997) On Stock Market Returns and Monetary Policy. Journal of Finance, 52, 635-654. https://doi.org/10.1111/j.1540-6261.1997.tb04816.x

[5] Bomfim, A.N. (2003) Pre-Announcement Effects, News Effects, and Volatility: Monetary Policy and the Stock Market. Journal of Banking Finance, 27, 133-151.

[6] Kearney, A. and Lombra, R. (2004) Stock Market Volatility, the News, and Monetary Policy. Journal of Economics and Finance, 28, 252-259. https://doi.org/10.1007/BF02761615

[7] Graham, M., Nikkinen, J. and Sahlstrom, P. (2003) Relative Importance of Scheduled Macroeconomic News for Stock Market Investors. Journal of Economics and Finance, 27, 153-165. https://doi.org/10.1007/BF02827216

[8] Nikkinen, J., Omran, M., Sahlstrom, P. and Aijo, J. (2006) Global Stock Market Reactions to Scheduled U.S. Macroeconomic News Announcements. Global Finance Journal, 17, 92-104.

[9] Chen, E.T.J. and Clements, A. (2007) S \& P 500 Implied Volatility and Monetary Policy Announcements. Finance Research Letters, 4, 227-232.

[10] Gospodinov, N. and Jamali, I. (2010) Stock Market Volatility, Federal Funds Rate Surprises and Economic Factors. International Conference on Applied Economics, Athens, 18 June 2010, 201-214.

[11] Marshall, A., Musayev, T., Pinto, H. and Tang, L. (2012) Impact of News Announcements on the Foreign Exchange Implied Volatility. Journal of International Financial Markets, Institutions \& Money, 22, 719-737.

[12] Aijo, J. (2008) Impact of US and UK Macroeconomic News Announcements on the Return Distribution Implied by FTSE-100 Index Options. International Review of Financial Analysis, 17, 242-258.

[13] Shaikh, I. and Padhi, P. (2013) The Information Content of Implied Volatility Index (India VIX). Global Business Perspectives, 1, 359-378. https://doi.org/10.1007/s40196-013-0025-4

[14] Shaikh, I. and Padhi, P. (2016) On the Relationship between Implied Volatility Index and Equity Index Returns. Journal of Economic Studies, 43, 27-47. https://doi.org/10.1108/JES-12-2013-0198

[15] Nelson, D. (1991) Conditional Heteroscedasticity in Asset Returns: A New Approach. Econometrica, 59, 347-370. https://doi.org/10.2307/2938260

[16] Engle, R.F., Lilien, D. and Robins, R. (1987) Estimating Time-Varying Risk Premia in the Term Structure: The ARCH-M Model. Econometrica, 55, 391-407. https://doi.org/10.2307/1913242

[17] Engle, R.F. (1982) Autoregressive Conditional Heteroscedasticity with Estimates of the Variance of United Kingdom Inflation. Econometrica, 50, 987-1007. 
Submit or recommend next manuscript to SCIRP and we will provide best service for you:

Accepting pre-submission inquiries through Email, Facebook, LinkedIn, Twitter, etc. A wide selection of journals (inclusive of 9 subjects, more than 200 journals)

Providing 24-hour high-quality service

User-friendly online submission system

Fair and swift peer-review system

Efficient typesetting and proofreading procedure

Display of the result of downloads and visits, as well as the number of cited articles Maximum dissemination of your research work

Submit your manuscript at: http://papersubmission.scirp.org/

Or contact tel@scirp.org 